\title{
Influence of the Carbon: Nitrogen Ratio of the Growth Medium on the Cellular Composition and the Ability of the Methylotrophic Yeast Hansenula polymorpha to Utilize Mixed Carbon Sources
}

\author{
By TH. EGLI ${ }^{*}$ AND J. R. QUAYLE ${ }^{\dagger} \dagger$ \\ ${ }^{1}$ Swiss Federal Institute for Water Resources and Water Pollution Control, Swiss Federal \\ Institutes of Technology, $\mathrm{CH}-8600$ Dübendorf, Switzerland \\ ${ }^{2}$ Department of Microbiology, The University, Sheffield S10 2TN, UK
}

(Received 13 January 1986; revised 8 March 1986)

\begin{abstract}
The methylotrophic yeast Hansenula polymorpha was grown in a chemostat with a medium containing a mixture of glucose $\left(\mathrm{C}_{6}\right)$ and methanol $\left(\mathrm{C}_{1}\right)\left(87.8 \% \mathrm{C}_{6}: 12 \cdot 2 \% \mathrm{C}_{1}\right.$, w/w) as sole carbon source and $\mathrm{NH}_{4}^{+}$as sole nitrogen source. At a constant growth rate $\left(D 0.10 \mathrm{~h}^{-1}\right)$ the influence of the carbon:nitrogen ratio $(C: N)$ of the inflowing medium on the cellular and enzymic composition of the cells was studied. Three distinct growth regimes were recognized. A medium with a $\mathrm{C}: \mathrm{N}$ ratio $<12$ resulted in carbon-limited growth (high cellular protein content, low carbohydrate content) and under these conditions glucose and methanol were utilized simultaneously. A medium with a $\mathrm{C}: \mathbf{N}$ ratio $>31$ resulted in nitrogen-limited growth (low protein but high carbohydrate content of the cells) and the cells metabolized only glucose. A transition growth regime was observed during growth on media with intermediate $C: N$ ratios $(12<\mathrm{C}: \mathrm{N}>31)$. When assessed from both substrate consumption and cellular composition, growth was double-substrate (carbon and nitrogen)-limited. In this transition growth regime, changes in carbon metabolism and the cellular and enzymic composition of the cells were found. With increasing $\mathrm{C}: \mathrm{N}$ ratios in the growth medium a gradual repression of the synthesis of methanol-assimilating and dissimilating enzymes was found. This effect was most pronounced for alcohol oxidase, and as a consequence the cells switched from the utilization of the carbon substrate mixture to growth on glucose alone. The data presented suggest that the range within which double-substrate-limited growth can be expected is predictable from the composition of cells grown under single substrate limitation.
\end{abstract}

\section{INTRODUCTION}

In all ecosystems one of the key factors controlling the rate of cell growth is the availability of nutrients. In contrast to multicellular organisms, microbes can adapt relatively quickly to various nutrient limitations by changing their cellular composition. Single nutrient limitations such as carbon, nitrogen or inorganic ions have been much studied but little attention has been directed to the fact that growth, as it occurs in nature, is not necessarily limited by a single nutrient. Microbes are unlikely to grow over an extended period of time under 'steady-state' conditions but rather under conditions where the supply of nutrients fluctuates considerably. Only recently have microbiologists started to investigate the physiology and growth behaviour of microbes under multi-substrate-limited, gradient or transient growth conditions (e.g. Dijkhuizen, 1979; Gottschal, 1980; Wimpenny et al., 1983; Leegwater, 1983).

† Present address: University of Bath, Bath BA2 7AY, UK.

Abbreviations: $\mathrm{C}_{1}$, methanol; $\mathrm{C}_{6}$, glucose; $c_{0}, n_{0}$, concentration of carbon or nitrogen, respectively, in the inflowing medium $\left(\mathrm{g} \mathrm{l}^{-1}\right) ; c, n$, concentration of carbon or nitrogen, respectively, in the culture liquid $\left(\mathrm{g}^{-1} ; \mathrm{mg}^{-1}\right) ; D$, dilution rate $\left(\mathrm{h}^{-1}\right) ; q_{\mathrm{C}}, q_{\mathrm{C}_{6}}, q_{\mathrm{C}_{1}}, q_{\mathrm{N}}$, specific rate of carbon, glucose, methanol or nitrogen consumption, respectively [g substrate $\left(\mathrm{g}\right.$ biomass) ${ }^{-1} \mathrm{~h}^{-1}$ ]; $x$, biomass concentration $\left(\mathrm{gl}^{-1}\right) ; Y_{\mathrm{X} / \mathrm{C}}, Y_{\mathrm{X} / \mathrm{N}}$, growth yield with respect to carbon or nitrogen, respectively [g biomass (g substrate) ${ }^{-1}$ ]; GDH, glutamate dehydrogenase; GS, glutamine synthetase; GOGAT, glutamate synthase. 
During double-substrate-limited growth of methylotrophic yeasts with glucose and methanol (Egli et al., 1980, 1982) the simultaneous utilization of glucose and methanol in chemostat cultures was strongly dependent on the nature of the growth limitation. During carbon-limited growth the cells were able to utilize both substrates simultaneously and completely, whereas under nitrogen limitation the synthesis of enzymes required for methanol utilization was repressed, and therefore glucose was the only source of carbon metabolized by the cells. The kinetics of this repression have also been studied (Egli, 1982). In an experiment where the ratio of $\mathrm{C}: \mathrm{N}$ in the feed to the chemostat was gradually raised to achieve nitrogen-limited growth, the cells were for some time under conditions where neither residual carbon (glucose and/or methanol) nor nitrogen $\left(\mathrm{NH}_{4}^{+}\right)$could be detected in the culture. This indicates that between carbon limitation (nitrogen in excess) and nitrogen limitation (carbon source in excess) an additional growth regime exists where growth is limited by both nutrients. As the growth of microbes under such transition conditions has only been reported twice (Hueting \& Tempest, 1979; Gräzer, 1985) we decided to study the phenomenon in more detail and to investigate the influence of the $\mathrm{C}: \mathrm{N}$ ratio in the inflowing medium on the physiology of a methylotrophic yeast, particularly its ability to utilize mixtures of glucose and methanol simultaneously.

\section{METHODS}

Organism and cultivation. Hansenula polymorpha (CBS 4732) was grown in continuous culture ( $37^{\circ} \mathrm{C}, \mathrm{pH} 5.0$ ) on a synthetic medium (Egli \& Fiechter, 1981). A mixture of glucose $\left(\mathrm{C}_{6}\right)$ and methanol $\left(\mathrm{C}_{1}\right)$ of constant composition $\left(87.8 \%, \mathrm{C}_{6}: 12.2 \% \mathrm{C}_{1}, \mathrm{w} / \mathrm{w}\right)$ was used as the sole source of carbon and energy $; \mathrm{NH}_{4}^{+}$was the only source of nitrogen. The $\mathrm{C}: \mathrm{N}$ ratio in the inflowing medium was varied by changing the ratio $\mathrm{C}_{6} / \mathrm{C}_{1}$-mixture: $\mathrm{NH}_{4}^{+}$. The $\mathrm{C}: \mathrm{N}$ ratio of the medium indicated on the abscissa in the Figures was always calculated on the basis of total carbon from both glucose and methanol, whether utilized or not, and of nitrogen from $\mathrm{NH}_{4}^{4}$. To avoid wall growth due to methanol accumulation in the fermenter, the concentration of this substrate in the feed was always kept below $1.2 \mathrm{~g} \mathrm{l}^{-1}$. Dissolved oxygen tension was kept above $50 \%$ air saturation and the concentration of dry biomass in the fermenter was always lower than $5.0 \mathrm{~g} \mathrm{l}^{-1}$ to ensure that growth of the cells was always limited by either carbon or nitrogen.

Substrate concentrations. Glucose was measured enzymically (GOD-Perid test, Boehringer) and methanol was analysed by gas chromatography as reported by Egli et al. (1983). The detection limits for glucose and methanol were $2.0 \mathrm{mg} \mathrm{l}^{-1}$ and $1.0 \mathrm{mg} \mathrm{l}^{-1}$, respectively. $\mathrm{NH}_{4}^{+}$was measured spectrophotometrically using the indophenol method of Scheiner (1976). The reproducibility of the measurement of residual $\mathrm{NH}_{4}-\mathrm{N}$ was $< \pm 5 \%$ at concentrations $>0.10 \mathrm{~g} \mathrm{I}^{-1}$; between 0.10 and $0.0005 \mathrm{~g} \mathrm{l}^{-1}$ it was $< \pm 20 \%$ and reproducible measurements were not possible at concentrations lower than $0.0005 \mathrm{~g} \mathrm{NH}_{4}^{+} 1^{-1}$. To avoid substrate losses due to substrate consumption by the cells after sampling, the residual concentrations of glucose, methanol and $\mathrm{NH}_{4}^{+}$in the culture medium were assayed by the filtration technique described by Egli et al. (1983). With this technique the cells could be separated from the medium in less than $0.5 \mathrm{~s}$.

Cellular components. For dry weight measurements the cells were collected by centrifugation, washed twice with distilled water and dried to constant weight at $105^{\circ} \mathrm{C}$. Parallel samples varied by $< \pm 1 \%$. For the determination of cellular components, the cells were collected from the chemostat outlet and immediately cooled to $0^{\circ} \mathrm{C}$; they were then harvested by centrifugation at $4^{\circ} \mathrm{C}$, washed twice with sodium phosphate buffer $(50 \mathrm{mM}, \mathrm{pH} 7.0)$, freeze-dried and stored. Before the individual analyses, the freeze-dried cells were dried again over phosphorus pentoxide.

The content of carbon, hydrogen and nitrogen in freeze-dried cells was measured with a $\mathrm{C}, \mathrm{H}, \mathrm{N}$-Analyzer model 185 ( $F$ \& M Scientific). All values reported are the mean of at least three determinations and the deviations for $\mathrm{C}, \mathrm{H}$ and $\mathrm{N}$ for separate samples were always $< \pm 3.5 \%, \pm 11.9 \%$ and $\pm 3.7 \%$, respectively, of the absolute value.

The biuret method, as described by Herbert et al. (1971), was used for the determination of the protein content of freeze-dried cells.

Glycogen was measured by the method of Becker (1978).

The content of total carbohydrates was determined by the phenol method described by Herbert et al. (1971).

Enzyme assays. Cell-free extracts were prepared as described by Egli et al. (1983). All enzyme assays were done at $37^{\circ} \mathrm{C}$. The following enzymes were measured according to previously published methods: alcohol oxidase (EC 1.1.3.13; van Dijken et al., 1976), dihydroxyacetone kinase (van Dijken et al., 1978), formaldehyde dehydrogenase (EC 1.2.1.1; Egli et al., 1980), formate dehydrogenase (EC 1.2.1.2; Egli et al., 1980), glucose-6phosphate dehydrogenase (EC 1.1.1.49; Kornberg \& Horecker, 1955), glucose-6-phosphate isomerase (EC 5.3.1.9; Egli et al., 1983), 6-phosphogluconate dehydrogenase (EC 1.1.1.44; Egli et al., 1982), ribose-5phosphate isomerase (EC 5.3.1.6; Wood, 1970), ribulose-5-phosphate 3-epimerase (EC 5.1.3.1; Wood, 1970), 
transaldolase (EC 2.2.1.2; Tchola \& Horecker, 1966), transketolase (EC 2.2.1.1; Waites \& Quayle, 1981). The assay for $\mathrm{NADP}^{+}$-dependent glutamate dehydrogenase (EC 1.4.1.2) contained, per $\mathrm{ml}$ : potassium phosphate buffer pH 7.8, $100 \mu \mathrm{mol}$; 2-oxoglutarate, $3.3 \mu \mathrm{mol}$; $\mathrm{NH}_{4} \mathrm{Cl}, 33.3 \mu \mathrm{mol}$; NADPH, $0.50 \mu \mathrm{mol}$; and cell-free extract. The reaction was started by adding 2-oxoglutarate. The Lowry method was used to determine the protein concentrations in cell-free extracts. Bovine serum albumin (Armour) was used as the standard.

Enzyme units. The specific activities of all enzymes are expressed as the rate of substrate consumption (or

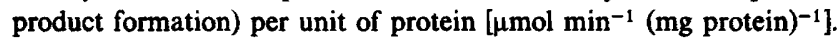

\section{RESULTS}

$H$. polymorpha was grown in chemostat culture $\left(D 0 \cdot 10 \mathrm{~h}^{-1}\right)$ on a glucose-methanol mixture of constant composition, and with $\mathrm{NH}_{4}^{+}$as sole nitrogen source, as described in Methods. The experiment was started by growing cells on the medium with the lowest $\mathrm{C}: \mathrm{N}$ ratio used in this study. After analysis of the resulting steady-state the ratio was increased stepwise. The C:N ratios, the composition of the media used and the exact residual concentrations of the substrates of interest are given in Table 1. On the basis of substrate utilization by the cells, and their cellular and enzymic composition, three different growth regimes could be recognized as the $\mathrm{C}: \mathrm{N}$ ratio of the supplied medium was changed. The most important characteristics of these regimes are summarized in Table 2 . In all the figures, the transition growth regime is indicated by a shaded area.

\section{Table 1. Substrate and dry biomass concentrations during cultivation of $H$. polymorpha}

$H$. polymorpha was grown in a chemostat at a constant dilution rate of $0.10 \mathrm{~h}^{-1}$ with media of different $\mathrm{C}: \mathrm{N}$ ratios. All concentrations are given in $\mathrm{g}^{\mathbf{1}^{-1}}$.

\begin{tabular}{|c|c|c|c|c|c|c|c|}
\hline \multicolumn{4}{|c|}{$\begin{array}{l}\text { Substrate concentrations } \\
\text { in the inflowing medium }\end{array}$} & \multicolumn{4}{|c|}{$\begin{array}{l}\text { Dry cell weight formed } \\
\text { and residual substrate } \\
\text { concentrations }\end{array}$} \\
\hline$C: N$ & $\mathrm{C}_{6}$ & $\mathrm{C}_{1}$ & $\mathrm{NH}_{4}^{+}-\mathrm{N}$ & Dry wt & $\mathrm{C}_{6}$ & $C_{1}$ & $\mathrm{NH}_{4}^{+}-\mathrm{N}$ \\
\hline 1.00 & $4 \cdot 56$ & 0.67 & $2 \cdot 088$ & $2 \cdot 71$ & - & - & 1.837 \\
\hline $2 \cdot 79$ & 4.56 & 0.67 & 0.746 & $2 \cdot 86$ & - & - & 0.509 \\
\hline 6.63 & $4 \cdot 28$ & 0.64 & 0.294 & $2 \cdot 70$ & - & - & 0.1233 \\
\hline $11 \cdot 32$ & $4 \cdot 15$ & 0.61 & $0 \cdot 167$ & $2 \cdot 40$ & - & - & $0-0161$ \\
\hline $14 \cdot 46$ & 4.44 & 0.63 & 0.139 & 2.44 & - & - & 0.0035 \\
\hline 15.89 & $4 \cdot 34$ & 0.62 & 0.124 & $2 \cdot 61$ & - & - & 0.0005 \\
\hline 18.40 & 4.61 & 0.64 & 0.113 & 2.69 & - & - & - \\
\hline 21.95 & $5 \cdot 53$ & 0.72 & 0.113 & $3 \cdot 20$ & - & 0.007 & - \\
\hline 26.73 & 6.69 & 0.91 & 0.113 & 3.79 & - & 0.78 & - \\
\hline 35.04 & 8.85 & $1 \cdot 13$ & 0.113 & $4 \cdot 74$ & 0.0038 & 1.04 & - \\
\hline $40 \cdot 13$ & 6.99 & 0.90 & 0.078 & 3.08 & 0.0094 & 0.84 & - \\
\hline $59 \cdot 11$ & 5.89 & 0.82 & 0.045 & 1.42 & 2.07 & 0.78 & - \\
\hline
\end{tabular}

Table 2. Characterization of different growth regimes observed during the cultivation of H. polymorpha

$H$. polymorpha was grown in a chemostat at a constant dilution rate of $0 \cdot 10 \mathrm{~h}^{-1}$ with media of different $\mathrm{C}: \mathrm{N}$ ratios. All concentrations are given in $\mathrm{mg}^{-1}$.

\begin{tabular}{|c|c|c|c|c|c|c|c|}
\hline \multirow[b]{2}{*}{$\begin{array}{l}\text { Growth } \\
\text { regime }\end{array}$} & \multirow{2}{*}{$\begin{array}{c}\mathrm{C}: \mathrm{N} \text { ratio } \\
\text { range of } \\
\text { media }\end{array}$} & \multicolumn{3}{|c|}{$\begin{array}{c}\begin{array}{c}\text { Residual substrate } \\
\text { in the culture }\end{array} \\
\end{array}$} & \multirow{2}{*}{$\begin{array}{c}\text { Cell } \\
\text { protein } \\
\text { content }\end{array}$} & \multirow{2}{*}{$\begin{array}{c}\text { Cell } \\
\text { carbohydrate } \\
\text { content }\end{array}$} & \multirow[b]{2}{*}{$\begin{array}{l}\text { Alcohol oxidase } \\
\text { (specific activity) }\end{array}$} \\
\hline & & $\overbrace{\mathrm{C}_{6}}$ & $\mathrm{C}_{1}$ & $\widetilde{\mathrm{NH}_{4}^{+}}$ & & & \\
\hline $\begin{array}{l}\text { Carbon } \\
\text { limitation }\end{array}$ & $\leqslant 11 \cdot 32$ & $<2$ & $<1$ & $>3.5$ & High & Low & High \\
\hline Transition & $\begin{array}{l}11.32<C: N \leqslant 18.40 \\
18.40<C: N \leqslant 26.73\end{array}$ & $\begin{array}{l}<2 \\
<2\end{array}$ & $\begin{array}{l}<1 \\
>1\end{array}$ & $\begin{array}{l}<3.5 \\
<3.5\end{array}$ & $\begin{array}{l}\text { Reduced } \\
\text { Reduced }\end{array}$ & $\begin{array}{l}\text { Enhanced } \\
\text { Enhanced }\end{array}$ & $\begin{array}{l}\text { Reduced } \\
\text { Low }\end{array}$ \\
\hline $\begin{array}{l}\text { Nitrogen } \\
\text { limitation }\end{array}$ & $\geqslant 35.04$ & $>2$ & $>1$ & $<3.5$ & Low & High & Low \\
\hline
\end{tabular}




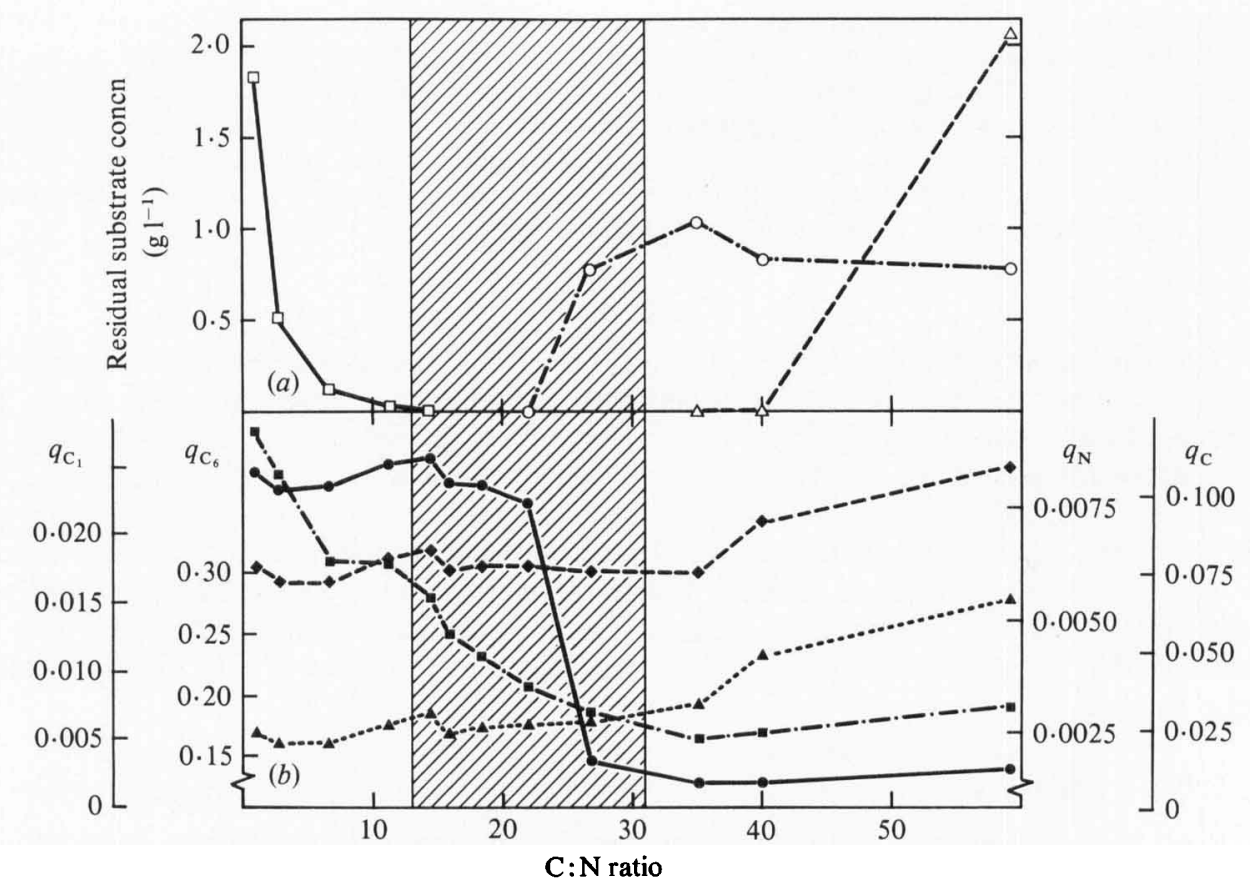

Fig. 1. Influence of the $\mathrm{C}: \mathrm{N}$ ratio in the inflowing medium on the utilization of a mixture of glucose and methanol $\left(87.8 \% \mathrm{C}_{6}: 12.2 \% \mathrm{C}_{1}, \mathrm{w} / \mathrm{w}\right)$ by $\mathrm{H}$. polymorpha growing in a chemostat at a dilution rate of $0 \cdot 10 \mathrm{~h}^{-1}$. (a) Residual concentration of $\mathrm{NH}_{4}^{+} \mathrm{N}(\square)$, glucose $(\triangle)$ and methanol $(O)$. (b) Specific substrate consumption rates $\left[\mathrm{g}(\mathrm{g} \text { dry } w \mathrm{ht})^{-1}\right]$ for glucose $\left(q_{\mathrm{C}_{6}}, \Delta\right)$, methanol $\left(q_{\mathrm{C}_{1}}, \mathrm{O}\right), \mathrm{NH}_{4}-\mathrm{N}\left(q_{\mathrm{N}}, \square\right)$ and total carbon $\left(q_{\mathrm{C}}, \diamond\right)$. The shaded area indicates the transition growth regime.

\section{Utilization of carbon and nitrogen sources}

The residual concentrations of glucose, methanol and $\mathrm{NH}_{4}^{+}$, and the specific rates of substrate consumption, are shown in Fig. 1 as a function of the $\mathrm{C}: \mathrm{N}$ ratio of the inflowing medium. As can be seen from the residual substrate concentrations in the culture (Fig. 1 $a$, Table 1) there were four different stable physiological states. (1) At low $C: N$ ratios $(\leqslant 11.32)$ growth was clearly carbon-limited, i.e., both carbon sources were simultaneously utilized to completion, whereas $\mathrm{NH}_{4}^{+}$was present in excess. (2) Growth with a medium of $11.32<\mathrm{C}: \mathrm{N} \leqslant 18.40$ resulted in complete utilization of the two carbon sources as well as the nitrogen source. (3) With a further increase of the $C: N$ ratio $(18.40<C: N \leqslant 26.73)$ repression of $C_{1}$-metabolism occurred and the cells switched from the utilization of $\mathrm{C}_{1} / \mathrm{C}_{6}$-mixtures to growth on glucose only. As a result methanol accumulated, whereas the residual concentrations of glucose and $\mathrm{NH}_{4}^{+}-\mathrm{N}$ were below 2.0 and $0.5 \mathrm{mg} \mathrm{l}^{-1}$, respectively. (4) $\mathrm{C}: \mathrm{N}$ ratios $\geqslant 35.04$ resulted in classic nitrogen-limited growth. Although more than $99.5 \%$ of the glucose supplied was metabolized by the cells at $\mathrm{C}: \mathrm{N}$ ratios of 35.04 and 40.13 the residual glucose concentrations were significant $\left(3.8\right.$ and $9.4 \mathrm{mg}^{-1}$, respectively).

The above pattern of substrate utilization is reflected in the specific rates of substrate consumption (Fig. 1 b). As long as both carbon sources were utilized to completion, their specific rates of consumption were constant and varied by $< \pm 5 \%\left(q_{\mathrm{C}_{1}} 0.024 \pm 0.001 \mathrm{~h}^{-1} ; q_{\mathrm{C}_{6}}\right.$ $\left.0.170 \pm 0.008 \mathrm{~h}^{-1} ; q_{\mathrm{C}} 0.077 \pm 0.003 \mathrm{~h}^{-1}\right)$. At a $\mathrm{C}: \mathrm{N}$ ratio $\geqslant 40.13$ the specific rate of glucose consumption was enhanced by $40-50 \%$, which indicates a change in the physiological state of the cells. At the same time a drop in growth yield from $Y_{\mathrm{X} / \mathrm{C}}=1.30 \pm 0.06$ to $Y_{\mathrm{X} / \mathrm{C}}=0.92$ was observed. Whether more carbon was channelled into product forming pathways or into dissimilation was not investigated. 


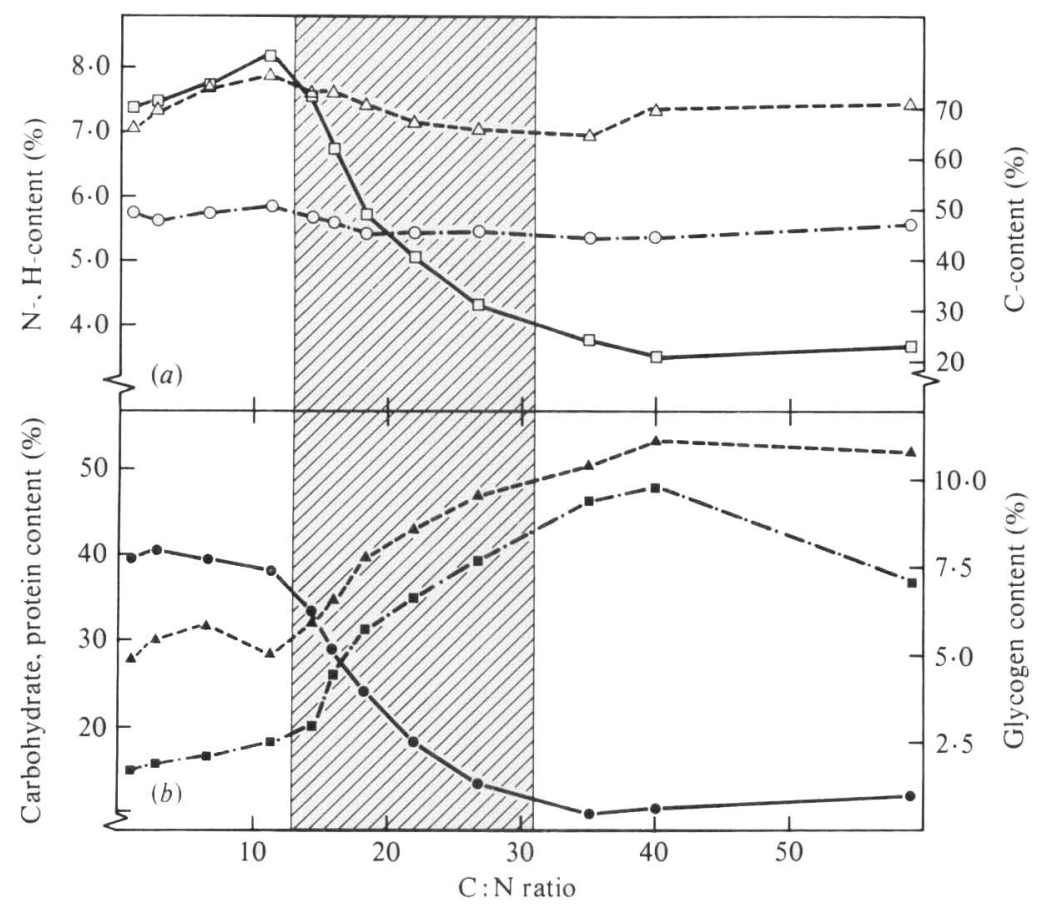

Fig. 2. Elemental and cellular composition of $H$. polymorpha as a function of the $C: N$ ratio in the inflowing medium. Culture conditions were as specified in Fig. 1. (a) Cellular content of carbon (O), hydrogen $(\triangle)$ and nitrogen $(\square)$. (b) Cellular content of protein $(O)$, glycogen $(\square)$ and total carbohydrate $(\Lambda)$. The shaded area indicates the transition growth regime.

The specific rate of nitrogen consumption was constant $\left(6.31 \times 10^{-3} \pm 0.03 \times 10^{-3} \mathrm{~h}^{-1}\right)$ both as long as the nitrogen source was present in excess, and during nitrogen-limited growth with $C: N$ ratios $\leqslant 35.04\left(q_{\mathrm{N}} 2.75 \times 10^{-3} \pm 0.35 \times 10^{-3} \mathrm{~h}^{-1}\right)$. In between carbon-limitation and nitrogen-limitation, $q_{\mathrm{N}}$ reflected the supply of nitrogen to the cells and decreased as the $\mathrm{C}: \mathbf{N}$ ratio of the inflowing medium was increased.

\section{Cellular composition}

Cells of $H$.polymorpha grown under the conditions described were analysed to determine their elemental composition ( $\mathrm{C}, \mathrm{N}, \mathrm{H}$ ) and their protein, total carbohydrate and glycogen content (Fig. 2). The hydrogen content showed little variation. The cellular carbon content was slightly higher in cells grown under carbon-limited conditions $(49.1 \pm 1.2 \%)$ than in cells grown under nitrogen-limited conditions $(45.7 \pm 0.9 \%$ ). The cellular nitrogen content was high $(7.5-8.0 \%)$ as long as the cells were supplied with a medium with a $C: N$ ratio $\leqslant 14.46$ and decreased gradually with increasing $C: N$ ratios. Growth under nitrogen-limited conditions $(C: N \geqslant 35.04)$ resulted in cells with a nitrogen content of approximately $3.7 \%$.

The total carbohydrate, glycogen and protein content (Fig. $2 b$ ) followed the expected pattern: low carbohydrate/high protein content during carbon-limited growth and high carbohydrate/ low protein content during nitrogen-limited growth. Transition from carbon-limited cell composition to nitrogen-limited cell composition was a gradual process; within the range of $\sim 13<\mathrm{C}: \mathrm{N}<\sim 30$ the cell was able to adjust its composition in response to pertaining environmental conditions. It should be noted that the carbohydrate content assay includes contributions from both DNA and RNA. 


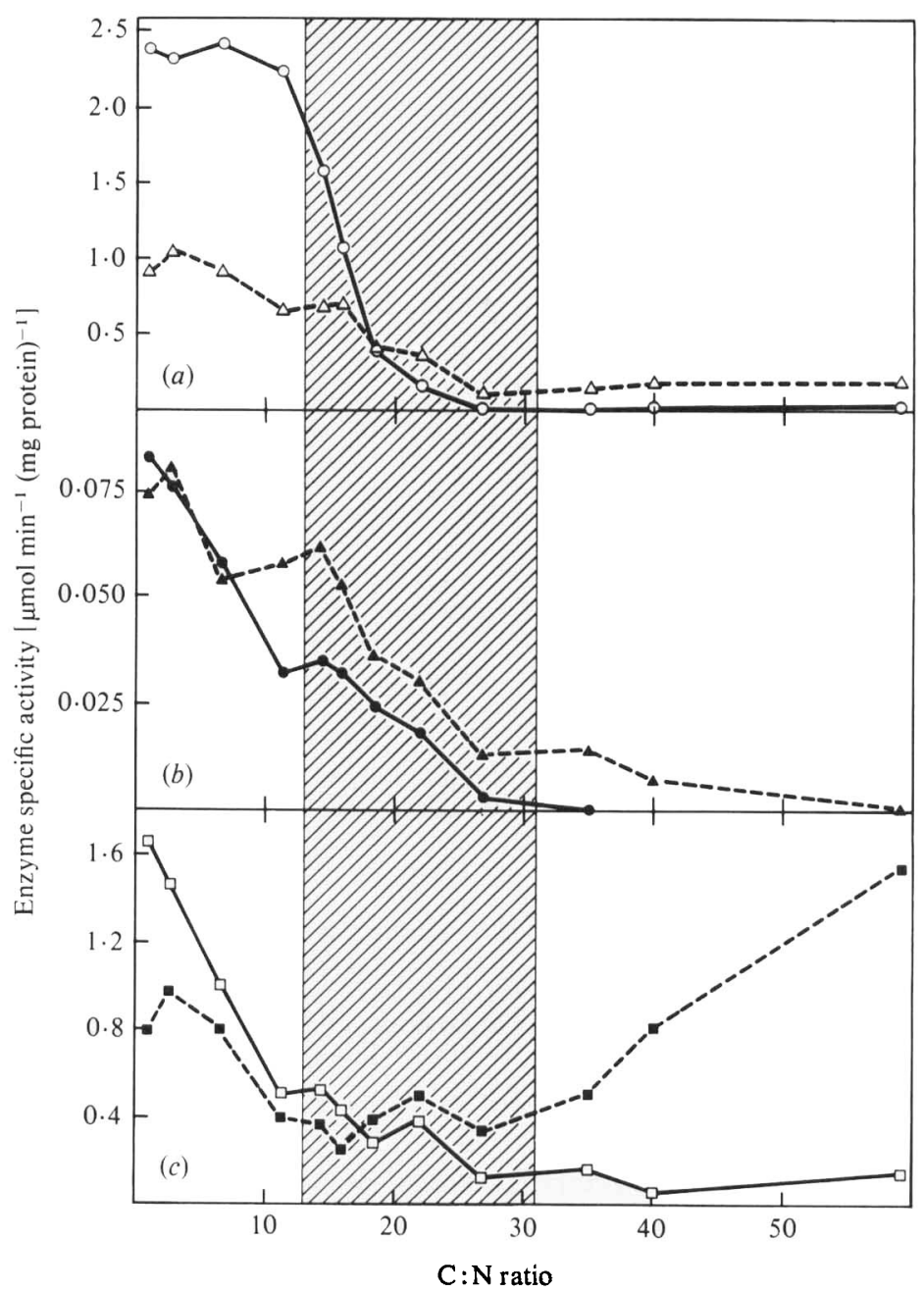

Fig. 3. Enzyme specific activities in cell-free extracts of $H$. polymorpha as a function of the $\mathrm{C}: \mathrm{N}$ ratio in the inflowing medium. Culture conditions were as specified in Fig. 1. (a) Alcohol oxidase (O), formaldehyde dehydrogenase $(\Delta) ;(b)$ formate dehydrogenase $(O)$, dihydroxyacetone kinase $(\Delta) ;(c)$ ribulose-5-phosphate epimerase $(\square)$, ribose-5-phosphate isomerase $(\square)$. The shaded area indicates the transition growth regime.

\section{Specific activities of enzymes}

The specific activities of enzymes involved in the metabolism of glucose and methanol and in the assimilation of $\mathrm{NH}_{4}^{+}$are shown in Figs 3 and 4. As expected from the substrate utilization pattern (Fig. 1a) enzymes involved in the metabolism of methanol were synthesized under carbon-limited growth conditions and their synthesis was repressed when nitrogen was the growth-limiting substrate. However, two different regulatory patterns were observed. The peroxisomal enzyme alcohol oxidase (Fig. $3 a$ ) was synthesized at a reduced rate when the residual nitrogen concentration in the culture was between 16.1 and $3.5 \mathrm{mg} \mathrm{l}^{-1}$ $(11 \cdot 32<\mathrm{C}: \mathbf{N}<14 \cdot 46)$. Repression was complete when the $\mathrm{C}: \mathrm{N}$ ratio in the feed was $>21.95$. This clear onset of repression was not observed for the two methanol dissimilating enzymes formaldehyde and formate dehydrogenase, nor for the $\mathrm{C}_{1}$-assimilating enzyme dihydroxyacetone kinase (Fig. $3 a, b$ ).

Ribose-5-phosphate isomerase, ribulose-5-phosphate epimerase, transaldolase and transketolase take part in both the assimilation of $\mathrm{C}_{1}$-units from methanol (dihydroxyacetone pathway) and the metabolism of glucose. Except for ribose-5-phosphate isomerase, their specific activity 


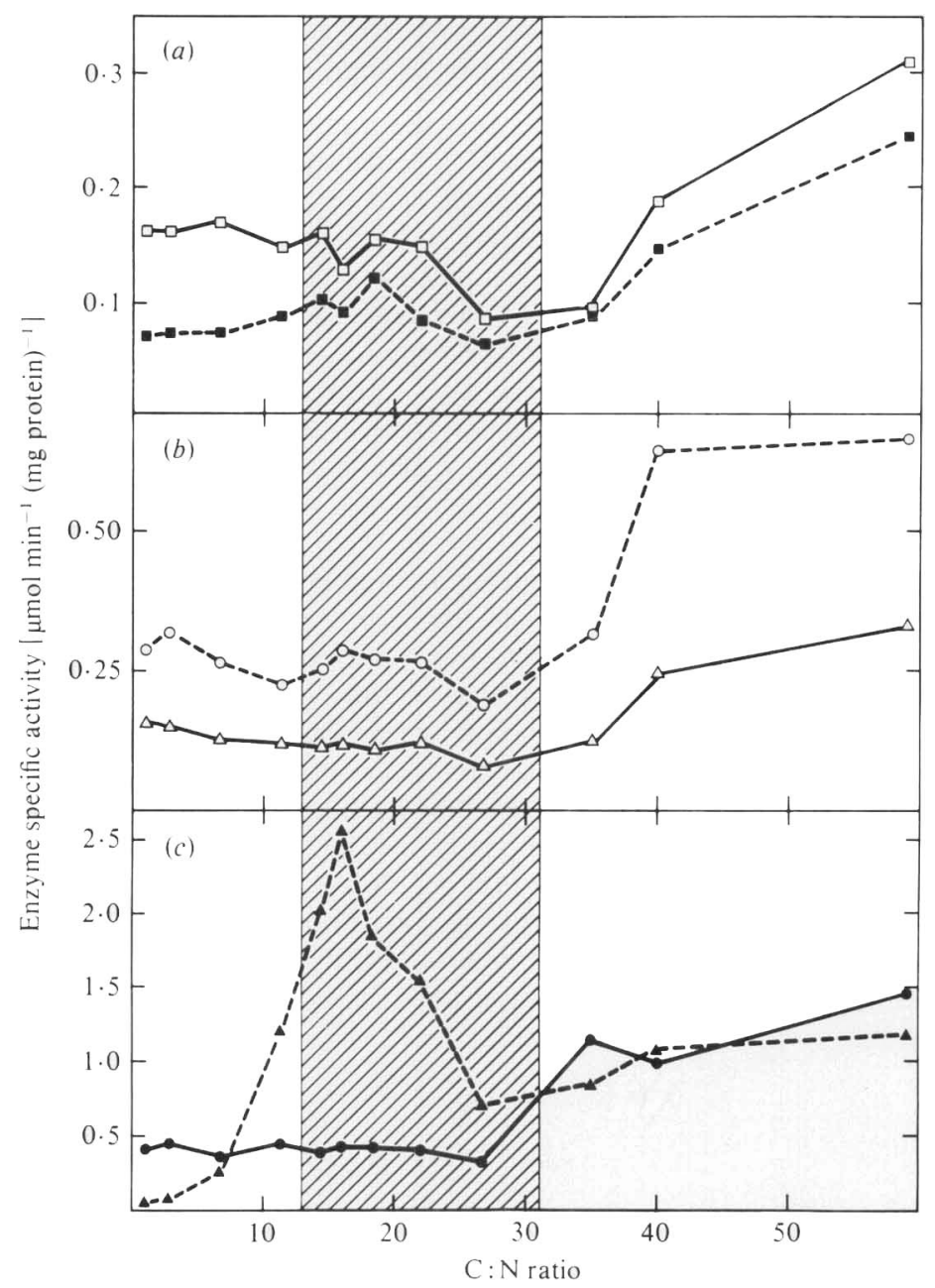

Fig. 4. Enzyme specific activities in cell-free extracts of $H$. polymorpha as a function of the $\mathrm{C}: \mathrm{N}$ ratio in the inflowing medium. Culture conditions were as specified in Fig. 1. (a) Transaldolase $(\square)$, transketolase $(\square) ;(b)$ glucose-6-phosphate dehydrogenase $(O)$, 6-phosphogluconate dehydrogenase $(\triangle) ;(c)$ glucose-6-phosphate isomerase $(\mathbf{O})$, glutamate dehydrogenase $(\boldsymbol{A})$. The shaded area indicates the transition growth regime.

was either approximately constant or decreased slightly with increasing $C: N$ ratios as long as no residual glucose was detected in the culture (Figs $3 c, 4 a$ ). When residual glucose was present their specific activity was enhanced two to threefold. Glucose-6-phosphate dehydrogenase, 6phosphogluconate dehydrogenase (Fig. $4 b$ ) and glucose-6-phosphate isomerase (Fig. 4c), three enzymes which are primarily involved in glucose metabolism, responded similarly. The specific activity of ribose-5-phosphate isomerase showed a very similar pattern to those enzymes involved in methanol metabolism. This indicates the important role of this enzyme in the rearrangement reactions of the dihydroxyacetone cycle of formaldehyde fixation.

In cell-free extracts of $H$. polymorpha the specific activity of glutamate dehydrogenase (GDH), the key enzyme in the assimilation of $\mathrm{NH}_{4}^{+}$in yeasts, increased approximately 50 -fold from $0.057 \mu \mathrm{mol} \mathrm{min}^{-1}$ (mg protein) $)^{-1}$ to a maximum of $2.575 \mu \mathrm{mol} \mathrm{min}^{-1}$ (mg protein) ${ }^{-1}$ as the $C: N$ ratio of the medium was increased from 1.00 to 15.89 . A further increase in the $C: N$ ratio to 30 resulted in a reduction of the specific activity of GDH to approximately $1 \mu \mathrm{mol} \mathrm{min}{ }^{-1}(\mathrm{mg}$ protein) ${ }^{-1}$; growth with $\mathrm{C}: \mathrm{N}$ ratios $>30$ had little further effect on the specific activity. 


\section{DISCUSSION}

\section{Modes of growth limitation}

In our experiment, the classic concept of growth limitation, namely that a linear relationship exists between biomass produced and substrate concentration (compare e.g. Stephenson, 1949; Tempest, 1969), is valid as long as either the nitrogen or the carbon source is clearly present in excess. The cellular composition with respect to total protein and carbohydrates is then not influenced by changes of the medium $C: N$ ratio. However, when media with $12<C: N>45$ are fed to the cells, and both the carbon and the nitrogen sources are completely metabolized, the concept of single substrate limitation no longer applies. Within this $\mathrm{C}: \mathrm{N}$ range, the organism responds to a change in the ratio of the two limiting substrates by altering its cellular composition to match the nutrient intake. However, if it is assumed that, instead of a single substrate, the combination of carbon and nitrogen source, at a fixed $\mathrm{C}: \mathrm{N}$ ratio, is growthlimiting, the concept of growth limitation within the transition growth regime can still be applied for a fixed growth rate.

Only two examples of double-substrate-limited growth of aerobic microbes have been reported. Hueting \& Tempest (1979) studied the pattern of overflow metabolite production by Klebsiella aerogenes during the transition from carbon to either potassium or ammonia limitation. Double substrate-limitation was also observed for a culture of Hyphomicrobium ZV620 growing with methanol and ammonia as the source of carbon and nitrogen (Gräzer, 1985). The phenomenon is probably widespread, occurring whenever organisms are grown under conditions of substrate limitation in media of different ratios of two substrates. The effect may be predicted from the known growth yields for the individual substrates as our own data illustrate. The concentration of biomass in the culture $(x)$ can be calculated from equation (1), where $c_{0}$ and $n_{0}$ are the concentrations of carbon and nitrogen in the feed, $c$ and $n$ are the residual concentrations of carbon and nitrogen in the culture, and $Y_{\mathrm{X} / \mathrm{C}}$ and $Y_{\mathrm{X} / \mathrm{N}}$ are the growth yields for carbon and nitrogen, respectively, measured under either carbon-limited or nitrogen-limited growth conditions.

$$
\begin{gathered}
x=\left(c_{0}-c\right) Y_{\mathrm{X} / \mathrm{C}}=\left(n_{0}-n\right) Y_{\mathrm{X} / \mathrm{N}} \\
c_{0} / n_{0}=Y_{\mathrm{X} / \mathrm{N}} / Y_{\mathrm{X} / \mathrm{C}}
\end{gathered}
$$

Because both $c$ and $n$ are zero under double-substrate-limitation, equation (1) can be rearranged to yield the $C: N$ ratio of the inflowing medium (equation 2). In order to estimate the minimum $\mathrm{C}: \mathrm{N}$ ratio at which the cells switch from carbon-limited to carbon/nitrogen-limited growth $Y_{\mathrm{X} / \mathrm{C}}$ and $Y_{\mathrm{X} / \mathrm{N}}$ measured under carbon-limited growth conditions (1.30 and 16.0, respectively) are inserted in equation 2 . The critical $C: N$ ratio of 12.3 calculated in this way corresponds closely with the experimentally observed value (Fig. $1 a$ ). Using $Y_{\mathrm{X} / \mathrm{C}}$ and $Y_{\mathrm{X} / \mathrm{N}}$ measured for a nitrogen-limited culture the same procedure would yield the critical medium $C: N$ ratio for the maximum $C: N$ ratio. Equation (1) indicates that in order to obtain doublesubstrate-limited growth with substrates $S_{1}$ and $S_{2}$, the growth yields $Y_{\mathrm{X} / \mathrm{S}_{1}}$ and/or $Y_{\mathrm{X} / \mathrm{S}_{2}}$ have to be different under $S_{1}$-limited and $S_{2}$-limited growth conditions. Therefore, the wider the range within which a cell component affected by the substrate(s) studied can vary, the more extended the double-substrate-limited growth regime will be.

Since the cellular composition does also vary with growth rate, and differences are more pronounced in slow growing cells (Herbert, 1976), one can expect the extension of the transition growth regime to become narrower with increasing growth rates.

\section{Cellular and enzymic composition}

The generally observed phenotypic response of microbes brought about by the limited availability of the two primary nutrients carbon and nitrogen may be summarized as follows (for reviews see Harder \& Dijkhuizen, 1983; Tempest et al., 1983; Harder et al., 1984; Tempest \& Neijssel, 1978). Carbon-limited growth results in cells with low carbohydrate and storage polymer and high protein contents. Such cells are usually able to use mixtures of carbon substrates simultaneously due to derepression of many catabolic enzymes. Cells grown under 
nitrogen-limitation have a reduced protein content and high carbohydrate and storage polymer contents; surplus carbon is frequently excreted into the medium in the form of an intermediary metabolite.

Two studies with $H$. polymorpha and Hyphomicrobium ZV620 (Gräzer, 1985) clearly document the different regulation patterns which can be observed for the individual enzymes as the $C: N$ ratio in the growth medium is gradually increased. In Hyphomicrobium $\mathrm{ZV620}$, where $\mathrm{NH}_{4}^{+}$is assimilated either via $\mathrm{GDH}$ at high residual $\mathrm{NH}_{4}^{+}$concentrations, or the high affinity enzyme system of glutamine synthetase (GS)/glutamate synthase (GOGAT), an 'all-or-nothing' type of response was observed for the specific activity of GDH. In this bacterium GDH was the main enzyme responsible for the assimilation of $\mathrm{NH}_{4}^{+}$during growth with $\mathrm{C}: \mathrm{N}$ ratios $\leqslant 7 \cdot 1$. However, growth with a $\mathrm{C}: \mathrm{N}$ ratio $<7.1$ resulted in a severe repression of the synthesis of GDH and its specific activity in cell-free extracts was reduced from $0.125(\mathrm{C}: \mathrm{N} 7 \cdot 1)$ to $0.02 \mu \mathrm{mol} \mathrm{min}^{-1}$ (mg protein) $)^{-1}$ (C:N 7.7). For $H$. polymorpha no similar regulatory pattern was observed for any of the enzymes assayed. It was only alcohol oxidase for which a clear onset and relatively stringent repression was found when the residual concentration of $\mathrm{NH}_{4}^{+}$dropped below $16 \cdot 1 \mathrm{mg} \mathrm{l}^{-1}$.

The specific activity pattern observed for GDH in $H$. polymorpha again differed markedly from all the other enzyme patterns. This enzyme is exclusively responsible for the assimilation of $\mathrm{NH}_{4}^{+}$in yeasts (Brown, 1976, 1980). Since yeast GDH has a low affinity for $\mathrm{NH}_{4}^{+}$the cells have to ensure the supply of nitrogen at low environmental $\mathrm{NH}_{4}^{+}$concentrations by increasing the amount of enzyme. $H$. polymorpha also responds to low external concentrations of $\mathrm{NH}_{4}^{+}$by the increased synthesis of this enzyme (Fig. 4c). It is notable that not only at low but also at relatively high $\mathrm{NH}_{4}^{+}$concentrations, at which this substrate is considered to be present in excess, the specific activity of NADP-dependent GDH inversely reflects the $\mathrm{NH}_{4}^{+}$concentration in the culture medium.

In methylotrophic yeasts the synthesis of the peroxisomal enzyme alcohol oxidase is repressed by high concentrations of glucose and various other carbon sources (Veenhuis et al., 1983). Alcohol oxidase activity was lost immediately when a culture of $H$.polymorpha was shifted from carbon-limited to nitrogen-limited growth conditions, although the glucose concentration in the culture was still undetectable $\left(<2 \mathrm{mg} \mathrm{l}^{-1}\right)$ (Egli, 1982). This indicated that the reduced availability of the nitrogen source might also regulate the synthesis of this enzyme. There is strong evidence from the data reported in this paper that nitrogen availability is indeed an important parameter in the regulatory control of alcohol oxidase. Repression started when the extracellular concentration of $\mathrm{NH}_{4}^{+}-\mathrm{N}$ was in the range $16 \cdot 1-3.5 \mathrm{mg} \mathrm{l}^{-1}$ and was co-ordinated with a reduction in the protein content of the cells. Increased synthesis of glycogen, on the other hand, started at $\mathrm{NH}_{4}^{+}-\mathrm{N}$ concentrations of $3.5-0.5 \mathrm{mg} \mathrm{l}^{-1}$ and residual glucose was only detectable at $\mathrm{C}: \mathrm{N}$ ratios $>35$. Regulation of the synthesis of alcohol oxidase by glucose catabolite repression and by nitrogen would not be surprising because under certain growth conditions this enzyme can account for up to $20 \%$ of the total cell protein (van Dijken et al., 1976).

The authors are indebted to Dr M. J. Waites for his generous help with some of the assimilatory enzyme assays and to C. M. Egli for her excellent technical assistance. The help of G. Hamer during the preparation of this manuscript is gratefully acknowledged. This work was financed by a Senior Visiting Fellowship (T.E.) from the Science and Engineering Research Council and by EAWAG (project no. 20-833).

\section{REFERENCES}

BECKER, J. U. (1978). A method of glycogen determination in whole yeast cells. Analytical Biochemistry 86, 56-64.

Brown, C. M. (1976). Nitrogen metabolism in bacteria and fungi. In Continuous Culture 6: Applications and New Fields, pp. 170-183. Edited by A. C. R. Dean, D. C. Ellwood, C. G. T. Evans \& J. Melling. Chichester: Ellis Horwood.
Brown, C. M. (1980). Ammonia assimilation and utilization in bacteria and fungi. In Microorganisms and Nitrogen Sources, pp. 511-535. Edited by J. W. Payne. Chichester: John Wiley.

VAN DiJken, J. P., OtTo, R. \& Harder, W. (1976). Growth of Hansenula polymorpha in a methanollimited chemostat. Archives of Microbiology 111, 137-144. 
VAN DijKen, J. P., HARder, W., Beardsmore, A. J. \& QUAYLE, J. R. (1978). Dihydroxyacetone: an intermediate in the assimilation of methanol by yeasts? FEMS Microbiology Letters 4, 97-102.

DIJKHUIZEN, L. (1979). Regulation of autotrophic and heterotrophic metabolism in Pseudomonas oxalaticus $O X 1$. PhD thesis, University of Groningen, Holland.

EGLI, TH. (1982). Regulation of protein synthesis in methylotrophic yeasts: repression of methanol dissimilating enzymes by nitrogen limitation. Archives of Microbiology 131, 95-101.

EGLI, TH. \& FIECHTER, A. (1981). Theoretical analysis of media used in the growth of yeast on methanol. Journal of General Microbiology 123, 365-369.

Egli, Th., VAN DiJken, J. P., VeEnhuIs, M., HARDER, W. \& FIECHTER, A. (1980). Methanol metabolism in yeasts: regulation of the synthesis of catabolic enzymes. Archives of Microbiology 124, 115-121.

EGLI, TH., KÄPPELI, O. \& FIECHTER, A. (1982). Regulatory flexibility of methylotrophic yeasts in chemostat cultures: simultaneous assimilation of glucose and methanol at a fixed dilution rate. Archives of Microbiology 131, 1-7.

Egli, Th., Lindley, N. D. \& Quayle, J. R. (1983). Regulation of enzyme synthesis and variation of residual methanol concentration during carbonlimited growth of Kloeckera sp. 2201 on mixtures of methanol and glucose. Journal of General Microbiology 129, 1269-1281.

GotTSCHAL, J. C. (1980). Mixotrophic growth of Thiobacillus $\mathrm{A} 2$ and its ecological significance. $\mathrm{PhD}$ thesis, University of Groningen, Holland.

GRÄZER, S. (1985). Chemostatstudie über die Regulation der ammoniumassimilierenden Enzyme in Hyphomicrobium ZV 620. Dissertation no. 7790, ETH, Zürich, Switzerland.

Harder, W. \& Dijkhuizen, L. (1983). Physiological responses to nutrient limitation. Annual Review of Microbiology 37, 1-23.

HARDER, W., DiJkHUIZEN, L. \& VeldKaMP, H. (1984). Environmental regulation of microbial metabolism. Symposia of the Society for General Microbiology 36, 51-95.

Herbert, D., Phipps, P. J. \& Strange, R. E. (1971). Chemical analysis of microbial cells. Methods in Microbiology 5B, 209-344.

Herbert, D. (1976). Stoicheiometric aspects of microbial growth. In Continuous Culture 6: Applications and New Fields, pp. 1-30. Edited by A. C. R. Dean, D. C. Ellwood, C. G. T. Evans \& J. Melling. Chichester: Ellis Horwood.
HuEting, S. \& TEMPEST, D. W. (1979). Influence of the glucose input concentration on the kinetics of metabolite production by Klebsiella aerogenes NCTC 418, growing in chemostat culture in potassium- or ammonium-limited environments. Archives of Microbiology 123, 189-194.

KORNBERG, A. \& HORECKER, B. L. (1955). Glucose-6phosphate dehydrogenase. Methods in Enzymology 1, 323-327.

LEEGWATER, M. P. M. (1983). Microbial reactivity: its relevance to growth in natural and artificial environments. PhD thesis, University of Amsterdam, Holland.

SCHEINER, D. (1976). Determination of ammonia and Kjeldahl nitrogen by indophenol method. Water Research 10, 31-36.

STEPHENSON, M. (1949). Growth and nutrition. In Bacterial Metabolism, 3rd edn, pp. 159-178. London: Longman, Green.

TCHOLA, O. \& HORECKER, B. L. (1966). Transaldolase. Methods in Enzymology 9, 499-505.

TEMPEST, D. W. (1969). Quantitative relationships between inorganic cations and anionic polymers in growing bacteria. Symposia of the Society for General Microbiology 19, 87-111.

Tempest, D. W. \& Neijssel, O. M. (1978). Ecophysiological aspects of microbial growth in aerobic nutrient-limited environments. Advances in Microbial Ecology 2, 105-153.

Tempest, D. W., Neijssel, O. M. \& Zevenboom, W. (1983). Properties and performance of microorganisms in laboratory culture: their relevance to growth in natural ecosystems. Symposia of the Society for General Microbiology 34, 119-152.

VEENHUIS, M., VAN DIJKEN, J. P. \& HARDER, W. (1983). The significance of peroxisomes in the metabolism of one-carbon compounds in yeasts. Advances in Microbial Physiology 24, 1-82.

Waites, M. J. \& QuAYLE, J. R. (1981). The interrelation between transketolase and dihydroxyacetone synthase activities in the methylotrophic yeast Candida boidinii. Journal of General Microbiology 124, 309-316.

Wimpenny, J. W. T., LovitT, R. W. \& CoOmbs, J. P. (1983). Laboratory model systems for the investigation of spatially and temporally organised microbial ecosystems. Symposia of the Society for General Microbiology 34, 67-117.

Wood, T. (1970). Spectrophotometric assay for Dribose-5-phosphate ketol-isomerase and for D-ribulose-5-phosphate 3-epimerase. Analytical Biochemistry 33, 297-306. 